\title{
HUBUNGAN STATUS GIZI DENGAN TUMBUH KEMBANG BALITA USIA 21-36 BULAN DI DESA BERINGIN DAN AIR DINGIN KELURAHAN BALAI GADANG PADANG
}

\author{
Ika Putri Ramadhani \\ Akademi Kebidanan Alifah, Padang, Sumatera Barat \\ Email: ikaputri005@gmail.com
}

\begin{abstract}
ABSTRAK
Berdasarkan data yang diperoleh dari Dinas Kesehatan Kota Padang tahun 2015, Puskesmas Air Dingin merupakan puskesmas yang pencapaian deteksi dini tumbuh kembang anak balita sangat rendah, yaitu pada tahun 2013 target (95,5\%) hanya terdeteksi $(92,6 \%)$ dan meningkat pada tahun 2015 target $(95 \%)$ hanya terdeteksi $(69,75 \%)$ dari total populasi balita sebanyak 1.838 jiwa. Tujuan penelitian ini untuk mengetahui hubungan status gizi dengan tumbuh kembang balita usia 21-36 bulan di Desa Beringin dan Air Dingin Kelurahan Balai Gadang Padang tahun 2017.

Jenis penelitian ini bersifat analitik dengan desain cross sectional. Penelitian ini dilakukan \pm 10 bulan. Populasi yaitu balita yang berusia 21-36 bulan, sampel penelitian diambil dengan menggunakan teknik Total population dengan jumlah sampel 64 orang. Data dikumpulkan dengan penimbangan berat badan berdasarkan umur balita dan KPSP tumbuh kembang. Data dianalisis secara univariat dan bivariat menggunakan uji Chi-Square $(\mathrm{p}=<0,05)$.

Hasil penelitian menjelaskan bahwa sebagian kecil $(34,4 \%)$ responden dengan tumbuh kembang meragukan, lebih dari separuh $(76,6 \%)$ responden memiliki status gizi baik. Dari hasil uji statistik Chi-Square ada hubungan yang bermakna antara status gizi dengan tumbuh kembang balita usia 21-36 bulan, dengan nilai p value 0,038.

Hasil penelitian diketahui ada hubungan status gizi dengan tumbuh kembang balita. Diharapkan pada petugas kesehatan dapat meningkatkan pelayanan kesehatan terutama dalam bidang status gizi balita dan untuk selalu meningkatkan pemantauan tumbuh kembang balita secara berkesinambungan dan melakukan stimulasi berkelanjutan pada balita yang memiliki tumbuh kembang meragukan, dengan memberikan penyuluhan dan leaflet.
\end{abstract}

Kata kunci : Status Gizi, Tumbuh Kembang balita

\section{ABSTRACT}

Based on data obtained from Padang City Health Office 2015, Public Health Center of Air Dingin is a health center that achieves early detection of very low growth of under five children, that is in 2013 target $(95,5 \%)$ only detected $(92,6 \%)$ and increase at in 2015 the target (95\%) is only detected (69.75\%) of the total population of under-fives as many as 1838 inhabitants. The purpose of this study to determine the relationship of nutritional status with the growth of infants aged 21-36 months in the village of Beringin and Air Cold Balur Gadang Padang Village in 2017.

This type of research is analytic with cross sectional design. This study was conducted \pm 10 months. The population is children aged 21-36 months, the research sample is taken by using total population technique with total sample 64 people. Data were collected by weight weighing based on toddler age and KPSP growth. Data were analyzed univariat and bivariate using Chi-Square test $(p=\langle 0,05)$.

The result of the study explained that a small part $(34,4 \%)$ of respondents with doubtful growth, more than half $(76,6 \%)$ of respondents have good nutritional status. From Chi-Square statistical test results there is a significant relationship between nutritional status with the growth of infants aged 21-36 months, with a value of $p$ value 0.038 .

The result of the research shows that there is correlation between nutritional status and the growth of infants. It is expected that health workers can improve health services, especially in the field of nutritional status of children under five and to always improve the continuous growth monitoring of children under five and perform continuous stimulation on toddlers who have dubious growth, by providing counseling and leaflets.

Keywords: Nutritional Status, Growing Toddler 


\section{PENDAHULUAN}

Keberhasilan pembangunan nasional suatu bangsa salah satunya ditentukan oleh ketersediaan Sumber Daya Manusia yang berkualitas. Untuk menjamin ketersediaan Sumber Daya Manusia yang berkualitas sangat dibutuhkan asupan gizi yang seimbang sedini mungkin yang dapat membantu dalam proses pertumbuhan dan perkembangan (Depkes, 2009).

Keadaan gizi yang baik dan sehat pada masa balita merupakan fondasi penting bagi kesehatannya di masa depan. Kekurangan gizi yang terjadi pada masa tersebut dapat mengakibatkan terganggunya pertumbuhan dan perkembangan (Sutomo, 2010).

Perkembangan terdiri atas perkembangan psikomotorik, afektif dan kognitif yang saling menunjang satu sama lain. Ranah perkembangan pada balita yang paling sering dinilai di layanan primer (puskesmas atau posyandu) adalah perkembangan psikomotorik yang terdiri atas perkembangan motorik halus, motorik kasar, bahasa-bicara, kemandirian dan sosial anak. Perkembangan psikomotorik sudah lazim disebut sebagai perkembangan saja yang dinilai dengan KPSP (Kuesioner Pra Skrining Perkembangan) (Depkes,2010).

Capaian indikator pelayanan kesehatan balita di Indonesia sebesar $75,82 \%$ yang berarti belum mencapai target setara yang sebesar $85 \%$. Di sumatera barat cakupan pelayanan kesehatan anak balita $71,11 \%$, sedangkan target setara cakupan pelayanan kesehatan anak balita sebesar $85 \%$ (profil kesehatan kota padang, 2014).

Berdasarkan penelitian yang dilakukan oleh Siti (2015) yang berjudul hubungan status gizi dengan perkembangan balita usia 4-5 tahun di Yogyakarta bahwa dari 34 responden didapatkan responden dengan status gizi baik dengan perkembangan sesuai terdapat $20(58,8 \%)$ responden dan terdapat 1 responden $(2,9 \%)$ yang status gizinya kurang dan perkembangan penyimpangan.

\section{Metoda Penelitian}

Jenis penelitian ini merupakan penelitian analitik dengan desain cross sectional study. Penelitian ini telah dilakukan di Desa Beringin dan Air Dingin Kelurahan Balai Gadang Padang pada bulan Oktober 2016 s/d Agustus 2017

Populasi pada penelitian ini adalah seluruh ibu-ibu yang mempunyai balita umur 21-36 bulan di Desa Beringin dan Air Dingin Kelurahan Balai Gadang Padang Tahun 2017 sebanyak 64 orang. Sampel pada penelitian ini adalah total populasi.

Instrumen yang digunakan dalam penelitian ini berupa timbangan berat badan dan KPSP yang telah di tetapkan oleh Dinas Kesehatan Kota Padang.

Data dikumpulkan mulai tanggal 6-11 Juli 2017 dengan cara kunjungan rumah ke rumah (door to door). Pada pengumpulan data peneliti dibantu oleh kader yang ikut serta menemani peneliti kerumah responden.

Analisis data dilakukan secara univariat dan bivariat. Data diolah secara komputerisasi.

\section{PEMBAHASAN}

\section{Analisa Univariat}

\section{a. Status Gizi}

Berdasarkan hasil analisis distribusi frekuensi status gizi responden pada penelitian ini dapat dilihat pada tabel 1 sebagai berikut :

Tabel 1. Distribusi Frekuensi Status Gizi Balita di Desa Beringin dan Air Dingin Kelurahan Balai Gadang Padang

\begin{tabular}{cccc}
\hline No & Status Gizi & Frekuensi (f) & $\%$ \\
\hline 1 & Gizi kurang & 15 & 23,4 \\
2 & Gizi baik & 49 & 76,6 \\
\hline & Total & 64 & 100 \\
\hline
\end{tabular}

Dari tabel 1 digambarkan bahwa dari 64 responden, didapatkan $15(23,4 \%)$ responden yang mengalami Gizi kurang.

\section{b. Tumbuh Kembang}

Berdasarkan hasil analisis distribusi frekuensi tumbuh kembang responden pada penelitian ini dapat dilihat pada tabel 4.2 sebagai berikut :

Tabel 2. Distribusi Frekuensi Tumbuh Kembang Balita Usia 21-36 Bulan di Desa Beringin dan Air Dingin Kelurahan Balai Gadang Padang

\begin{tabular}{cccc}
\hline No & $\begin{array}{c}\text { Tumbuh } \\
\text { Kembang }\end{array}$ & Frekuensi (f) & $\%$ \\
\hline 1 & Sesuai & 42 & 65,6 \\
2 & Meragukan & 22 & 34,4 \\
\hline & Total & 64 & 100 \\
\hline
\end{tabular}

Dari tabel 2 digambarkan bahwa dari 64 responden, didapatkan $22(34,4 \%)$ responden memiliki status tumbuh kembang yang meragukan berdasarkan tahap perkembangannya.

\section{Analisa Bivariat}


Analisa bivariat digunakan untuk melihat hubungan antara status gizi dengan tumbuh kembang balita usia 21 - 36 bulan.

\section{a. Hubungan Status Gizi dengan Tumbuh Kembang Balita}

Berdasarkan hasil analisis hubungan status gizi dengan tumbuh kembang balita usia 21-36 bulan didapatkan hasil sebagai berikut :

Tabel 3. Hubungan status gizi dengan tumbuh Kembang Balita Usia 21-36 Bulan di Desa Beringin dan Air Dingin Kelurahan Balai Gadang Padang

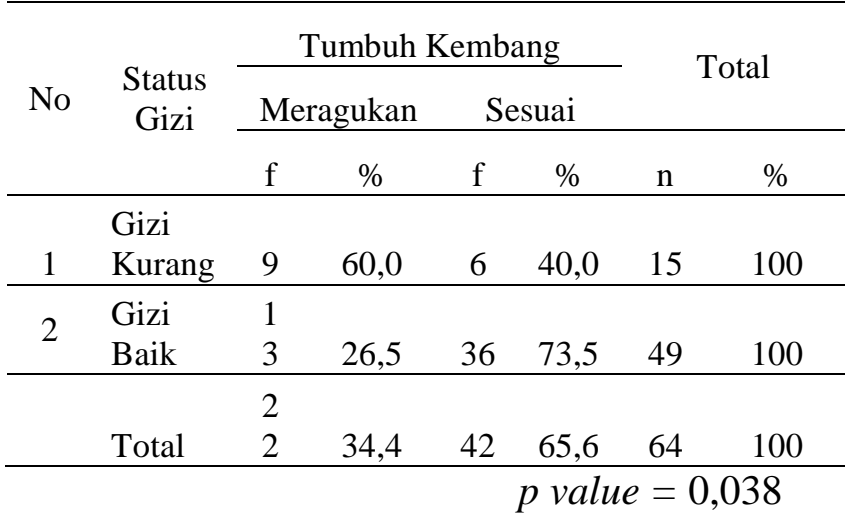

Tabel.3 hasil hubungan Status Gizi dengan Tumbuh Kembang Balita Usia 21-36 Bulan di Desa Beringin dan Air Dingin Kelurahan Balai Gadang Padang Tahun 2017 diketahui dari 15 responden yang gizi kurang didapatkan $9(60,0 \%)$ responden dengan tumbuh kembang meragukan, lebih tinggi dibandingkan dengan responden yang tumbuh kembangnya sesuai yaitu sebanyak 6 $(40,0 \%)$ responden.

Hasil uji statistik chi-square $p$ value $<0,05$ di dapatkan bahwa ada hubungan yang bermakna antara Status Gizi dengan Tumbuh Kembang Balita Usia 21-36 Bulan di Desa Beringin dan Air Dingin Kelurahan Balai Gadang Padang Tahun 2017.

\section{SIMPULAN}

1. Lebih dari separuh $(76,6 \%)$ balita usia 21-36 bulan di Desa Beringin dan Air Dingin Kelurahan Balai Gadang memiliki status gizi baik.

2. Lebih dari separuh $(65,6 \%)$ balita usia $21-36$ bulan di Desa Beringin dan Air Dingin Kelurahan Balai Gadang memiliki status tumbuh kembang sesuai dengan tahap perkembangannya.

3. Terdapat hubungan yang bermakna antara status gizi dengan tumbuh kembang balita usia 21-36 bulan di Desa Beringin dan Air Dingin Kelurahan Balai Gadang.

\section{DAFTAR PUSTAKA}

Almatsier, S. 2010. Prinsip Dasar Ilmu Gizi, cetakan kesembilan, Jakarta: PT Gramedia Pustaka Utama.

Departemen kesehatan RI 2012.Deteksi Dini TumbuhKembang Anak. Pedoman Penatalaksanaan Stimulasi, Deteksi, Dan Intervensi Dini Tumbuh Kembang Anak Di Tingkat Pelayanan Kesehatan Dasar, Jakarta, 2012.

Depkes, 2007.Pedoman tumbuh kembang. Jakarta: Sumatera Barat.

Depkes, 2009. Pedoman Pelaksana Stimulasi, Deteksi Dan Intervensi Dini Tumbuh Kembang. Sumatera Barat.

Departemen kesehatan RI, 2016. Profil Kesehatan Indonesia Tahun 2009. Jakarta: Depkes RI.

Depkes, 2010. Pedoman Tumbuh Kembang. Jakarta: Sumatera Barat.

Departemen Gizi dan Kesehatan Masyarakat FKUI, 2011. Gizi dan Kesehatan.

Dinas Kesehatan Sumatera Barat, 2015. Profil Kesehatan Provinsi Sumatera Barat Tahun 2015. Padang : Dinkes Sumbar, 2014.

Dinas Kesehatan Sumatera Barat, 2014. Profil Kesehatan Provinsi Sumatera Barat Tahun 2014. Padang : Dinkes Sumbar, 2014.

Hamdini, dkk. 2014. Hubungan Status Gizi dengan Perkembangan Psikomotorik

Balita di Wilayah Kerja Puskesmas Lapai Padang Tahun 2014. Padang.

Hidajati, Z, 2009. Faktor Risiko Disfasia Perkembangan Pada Anak (Tesis). Semarang: Universitas Diponegoro Semarang.

Hidayat, A. Aziz Alimul, 2008. Pengantar Ilmu Kesehatan Anak Untuk Pendidikan Kebidanan, Jakarta: Salemba Medika.

http://www.komisi Nasional Perlindungan Anak.com/ diakses pada tanggal 20 Desember 2013.

Kementerian Kesehatan RI, 2010. Standar Antropometri Peniilaian Status Gizi Anak. Jakarta.

Kemenkes RI.2010. Keputusan Menteri Kesehatan Republik Indonesia No. 1995/Menkes/SK/XII/2010 Tentang Standar Pengukuran Antropometri Penilaian Status Gizi Anak. 
Mufida.2013. sindrom turner. Diakses September 01, 2015 dari http://wafif-mufidafk12.web.unair.ac.id/artikel.

Narendra, M.B. 2002. Tumbuh Kembang Anak Dan Remaja. Jakarta: EGC.

Notoatmojo, Soekidjo, 2010. Metodologi Penelitian Kesehatan. Jakarta: Rinepka Cipta.

Puskesmas Air Dingin Kota Padang, 2015. Data Status Gizi Balita Kelurahan Balai Gadang Tahun 2015.

Proverawati. 2010. Buku ajar gizi untuk kebidanan. Jogjakarta: Graham Medika.

Ratna.2016. Hubungan Status Gizi Dengan Perkembangan Anak Usia 1-5 Tahun di Posyandu Desa Sirnoboyo Kabupaten Wonogiri, vol 4, 47-55

Sodiaoetama, 2010. Ilmu Gizi Untuk Mahasiswa Dan Profesi. Jakarta: Dian Rakjat.

Setyawan. 2011. Penyakit Kretinisme. Artikel kesehatan diakses di http://ilmubgoes.blogspot.com.

Siti. 2015. Hubungan Status Gizi Dengan Perkembangan Balita Usia 4-5 Tahun di Tk Aisyiyah Bustanul Athfal Gendingan Yogyakatra Tahun 2015.Yogyakarta.

Soetjiningsih. 2013. Tumbuh Kembang Anak. Jakarta: EGC.

Soetjiningsih. 1995. Tumbuh Kembang Anak. Jakarta: EGC.

Suhardjo. 2005. Perencanaan Pangan dan Gizi. Jakarta: Bumi Aksara.

Sulistyawati,Ari. 2013. Deteksi tumbuh kembang anak, Jakarta: Salemba Medika

Supariasa, Nyoman I dewa,2012. Penilaian Status Gizi Edisi Revisi.Jakarta.: EGC.

Sutomo, B, dan Anggraini, D. Y. 2010. Makanan Sehat Pendamping ASI. Jakarta: PT. Agromedia Pustaka

Syamsu. Yusuf. 2012. Psikologi Perkembangan Anak dan Remaja. Bandung: PT Remaja Rosdakarya Widyastuti. 2009. Hubungan Riwayat Pemberian Asi ekslusif dengan status gizi bayi 6-12 bulan Di Nusa tenggara barat (NTB) Tahun 2007. Tesis Program Studi Epidiomologi Fakultas Kesehatan Masyarakat Universitas Indonesia Depok 2009.
William,dkk 2010. Gambaran Status Gizi Anak Dip Anti Asuhan Yayasan Terima Kasih Abadi Kecamatan Medan Barat Tahun 2010. Karya Tulis Ilmiah Fakultas Kedokteran Universutas Sumatera Utara Medan.

Wirjatmadi B. 2014. Gizi dan Kesehatan Balita. Cetakan pertama, Kencana Prenada Media Group: Jakarta

Wong,D.L. 2004. Pedoman Klinis Perawatan Pediatrik. Diterjemahkan oleh Monica Ester. Jakarta: EGC.

Zulaikhah, Siti. 2010. Hubungan Status Gizi dengan Perkembangan Anak Usia Sampai 3 Tahun Di Wilayah Kerja Puskesmas Gambirsari Kota Surakarta. URL:http://eprints.uns.ac.id/6213 / . Diakses 12 Juni 2015. 